\title{
AGgREGATION OF PLATELETS, PROLIFERATION OF ENDOTHELIAL CELLS AND MOTILITY OF CANCER CELLS ARE MEDIATED BY THE Bß1(15)-42 RESIDUE OF FIBRIN(OGEN)
}

\author{
Y. M. STOHNII ${ }^{1}$, M. V. RYZHYKOVA ${ }^{1}$, A. V. REBRIEV ${ }^{1}$, \\ M. D. KUCHMA', R. Y. MARUNYCH ${ }^{1}$, V. O. CHERNYSHENKO ${ }^{1 凶}$, \\ V. A. SHABLII', N. M. LYPOVA', O. Yu. SLOMINSKYI', \\ L. V. GARMANCHUK $K^{4}$, T. M. PLATONOVA ${ }^{1}$, S. V. KOMISARENKO \\ ${ }^{1}$ Palladin Institute of Biochemistry, National Academy \\ of Sciences of Ukraine, Kyiv, Ukraine; \\ ${ }^{2}$ Institute of Cell Therapy, Kyiv, Ukraine; \\ ${ }^{3}$ University of Louisville, USA; \\ ${ }^{4}$ ESC "Institute of Biology and Medicine", \\ Taras Shevchenko National University of Kyiv, Ukraine; \\ @e-mail: bio.cherv@gmail.com
}

Received: 23 December 2019; Accepted: 27 March 2020

The fibrinogen molecule contains multiple binding motifs for different types of cellular receptors, acting as a molecular link between coagulation and cell adhesion. In this study we generated a truncated form of the fibrinogen molecule lacking the B B1-42 sequence by site-specific proteolysis and evaluated the role of the fragment in adhesive capabilities of platelets, endothelial and cancer cells. Fibrinogen with the removed B B1-42 sequence and fibrin without the B B15-42 fragment (des $\beta 1-42$ fibrinogen and desAB $\beta 15-42$ fibrin) were obtained by proteolysis using the specific protease from the venom of Echis multisquamatis. The cleaved fragment was purified by HPLC and was identified using MALDI-TOF. ADP-and collagen-induced aggregation of washed platelets in the presence of fibrinogen desB B1-42 was studied using an aggregometer. Proliferation of mice aortic endothelial cells (MAEC) and human umbilical vein endothelial cells (HUVEC) was studied using the fibrin desABB15-42 as the scaffold. Cell viability was quantified by the MTT test (MAEC). Generation time was calculated for the estimation of proliferative activity of HUVEC. Lung cancer cell line H1299 was used to evaluate cancer cell motility in vitro using the scratch assay. Direct comparison of cellular behavior in the presence of truncated $v$ native forms demonstrated attenuated cell adhesion in the presence of fibrinogen desB B1-42 and fibrin desB B15-42. The platelet aggregation rate was only slightly decreased in the presence of fibrinogen desB B1-42 but resulted in 15-20\% disaggregation of adhered platelets. We also observed the substantial decrease of generation time of HUVEC and inhibition of viability of MAEC cells grown on scaffolds of a desABB15-42 matrix. Finally, desBB1-42 modulated the motility of H1299 cells in vitro and suppressed the wound healing by 20\% compared to the full-length fibrinogen. We postulate that fragment 1-42 of the $B \beta N$-domain of fibrinogen is not sufficient for platelet aggregation, however it may contribute to platelet clot formation in later stages. At the same time, this fragment may be important for establishing proper cell-to-cell contacts and cell viability of endothelial cells. Also, 1-42 amino acid fragment of the B $\beta N$-domain supported the migration of cancer cells suggesting that interactions of fibrinogen with cancer cells could be a target for anticancer therapy. The Bß1-42 fragment of fibrinogen contributes to efficient intracellular interactions of different types of cells, including platelets, endothelial cells and cancer cells.

Keywords: fibrinogen, adhesion, cell migration, endothelium, cell proliferation, platelets.

(C) 2020 Stohnii Y. M. et al. This is an open-access article distributed under the terms of the Creative Commons Attribution License, which permits unrestricted use, distribution, and reproduction in any medium, provided the original author and source are credited. 


\section{Introduction}

Fibrinogen is a large glycoprotein composed of three pairs of polypeptide chains bound by disulfide bonds into the complex structure represented by two peripheral D-regions, central E-region and flexible $\alpha \mathrm{C}$-region [1]. The amino acid composition of the whole fibrinogen molecule is A $\alpha 1-610, \mathrm{~B} \beta 1-461$ and $\gamma 1-411$. Each chain is presented in duplicate.

Because of its size and high concentration in blood plasma $(2-3 \mathrm{mg} / \mathrm{ml})$ fibrinogen can modulate various physiological processes apart from blood coagulation. In particular it can interact with various biological surfaces, binding non-specifically to glycocalyx and specifically to biological membranes mainly through integrin receptors. The fibrinogen molecule contains several active sites that can interact with cellular integrins, most of them were studied as ligands of platelet integrin IIbIIIa. The first of these are the C-terminal polypeptides of both $\gamma$-chains ( $\gamma 400-411)$ and RGD-residues of the A $\alpha$ chains $(\alpha 95-98, \alpha 572-574)[2,3]$. Another site that is important in fibrinogen interactions with IIbIIIa is the fragment $\gamma 312-324$ that is hidden in the fibrinogen molecule and exposed after its conversion to fibrin [4]. An important feature of fibrinogen binding to platelets is the role of platelet activation in this process. Fibrinogen cannot bind to non-activated platelets and interacts only with stimulated cells [5].

Among other parts of the fibrinogen molecule, the $\mathrm{B} \beta \mathrm{N}$-domains $(\mathrm{B} \beta 1-60)$ are supposed to interact with platelets [6]. In particular, peptides that are structural analogues of B $315-42$ residues of fibrinogen were shown to inhibit platelet aggregation [7]. These residues are also important for the spreading of platelets [8] but their role in platelet adhesion and aggregation is rather controversial.

At the same time, $\mathrm{B} \beta 15-42$ residues of $\mathrm{B} \beta \mathrm{N}$ domains can directly bind to VE-cadherin of endothelial cells (EC) $[9,10]$. This finding was confirmed in several studies and is supposed to be an important mechanism of the stabilization of the endothelial monolayer during inflammation [11, 12]. Another site of EC interactions with fibrinogen are very low-density lipoprotein receptors (VLDLR).
They also occur through B $\beta 15-42$ residues but have a rather regulatory role not contributing to the stability of interactions $[13,14]$.

EC as well as numerous other cells were shown to interact with the fibrinogen residue 1117-133 through intracellular adhesion molecule type 1 (ICAM-1) receptors [15]. Among other cells interacting with fibrinogen in an ICAM-1 dependent manner are leucocytes [16] and various types of cancer cells.

Fibrinogen is a component of the extracellular matrix and can regulate cancerogenesis and metastasis [17]. Binding to fibrinogen through ICAM-1 was shown for several types of cancer cells [18, 19]. Several studies indicate a regulatory role of this kind of interaction [20].

Here we would like to emphasize that different parts of the fibrinogen molecule can interact with cellular receptors more or less specifically, sometimes regulating the activity of different types of cells. Identification of the sites of fibrinogen that are important for molecular recognition provides not only information about mechanisms of cellular adhesion, but can also aid in the detection of targets for modulation of such important biological processes as thrombosis, atherogenesis or cancerogenesis.

In this work we focused on B $\mathrm{BN}$-domains of fibrinogen by studying their role in intracellular interactions of platelets, EC and cancer cells (lung cancer line H1299). To achieve this goal we removed the B $\beta 1-42$ peptide of the fibrinogen molecule using a specific protease and studied the changes in behavior of cells that interacted with this truncated form of fibrinogen. We studied aggregation of platelets, proliferation of EC and migration of cancer cells.

\section{Materials and Methods}

Fibrinogen. Fibrinogen was purified from blood plasma of healthy donors by the method of Belitser \& Varetska, its purity and clottability were controlled as previously described [21]. The procedure of blood collection was performed under the license of National Military Medical Clinical Center "Main Military Clinical Hospital” (Kyiv, Ukraine).

\footnotetext{
Abbreviations: EC - endothelial cells; VLDLR - very low density lipoprotein receptors; ICAM-1 - intracellular adhesion molecule type 1; HUVEC - human umbilical vein endothelial cells; MAEC - mouse aortic endothelial cells; TBS $0.05 \mathrm{M}$ Tris-HCl buffer of $\mathrm{pH} 7.4$ with $0.13 \mathrm{M} \mathrm{NaCl}$; ADP - adenosine diphosphate; MTT - 3-(4, 5-diethylthiazoly2-yl)-2,5-diphenyltetrazolium bromide; FBS - fetal bovine serum, BSA - bovine serum albumin; DMEM - Dulbecco's Modified Eagle's medium; FGF - fibroblast growth factor.
} 
Monomeric fibrin desA and desAB. Fibrin desA and desAB were prepared from human fibrinogen. Fibrin polymerization was initiated by $0.75 \mathrm{NIH} /$ $\mathrm{ml}$ thrombin-like enzyme from the venom of Agkistrodon halys halys for fibrin desA and $0.5 \mathrm{NIH} / \mathrm{ml}$ thrombin for fibrin desAB [22]. In the case of fibrin desAB, $0.1 \mathrm{ml}$ of $40 \mathrm{mM}$ monoiodacetic acid was added to the sample to avoid fibrin cross-linking. Each mixture was incubated for $30 \mathrm{~min}$ at $37^{\circ} \mathrm{C}$. The fully formed clot was removed from the incubation mixture by a glass stick, washed and re-dissolved in $0.125 \%$ acetic acid.

The truncated form of monomeric fibrin desA was prepared from human fibrinogen that was truncated by protease. Protease from the venom of Echis multisquamatis $(0.01 \mathrm{mg} / \mathrm{ml})$ was added to fibrinogen $(15 \mathrm{mg} / \mathrm{ml})$ and incubated in $0.05 \mathrm{M}$ Tris$\mathrm{HCl}$ buffer of $\mathrm{pH} 7.4$ with $0.13 \mathrm{M} \mathrm{NaCl}$ (TBS) for $45 \mathrm{~min}$ at $25^{\circ} \mathrm{C}$. Fibrin polymerization was induced by $0.5 \mathrm{NIH} / \mathrm{ml}$ thrombin and prepared as described above for fibrin desAB.

Washed platelets. Venous blood of healthy volunteers $(n=5)$ who had not taken any medication for 7 days was collected by venipuncture of the basilic vein using a $19 \mathrm{G}$ sterile needle. Blood was collected into sterile plastic $10 \mathrm{ml}$ tubes where it was mixed immediately with $38 \mathrm{~g} / 1$ sodium citrate ( 9 parts blood to 1 part sodium citrate). Blood was spun down at $160 \mathrm{~g}$ for $30 \mathrm{~min}$ at $25^{\circ} \mathrm{C}$. Platelet-rich plasma was collected and spun down again at $300 \mathrm{~g}$ for $15 \mathrm{~min}$. The pellet of platelets was re-suspended in $0.004 \mathrm{M}$ HEPES, $0.137 \mathrm{M} \mathrm{NaCl}, 0.0027 \mathrm{M} \mathrm{KCl}, 0.001 \mathrm{M}$ $\mathrm{MgCl}_{2}, 0.0056 \mathrm{mM}$ glucose, $0.003 \mathrm{M} \mathrm{NaH}_{2} \mathrm{PO}_{4}$, $0.35 \mathrm{mg} / \mathrm{ml}$ bovine serum albumin (BSA), $\mathrm{pH} 7.4$ to obtain a homogenous suspension of washed platelets as previously recommended [23].

Patients signed informed consent prior to blood sampling. This study was approved by the Ethics Committee of Palladin Institute of Biochemistry (03.09.2015, N7).

Human umbilical vein endothelial cells (HUVEC). Umbilical cord sampling was performed after the delivery. All birthing mothers signed informed consent prior to delivery. All manipulations were conducted under the license of the Ministry of Health of Ukraine given to the Institute of cell therapy, Kyiv, Ukraine. The umbilical vein was washed and poured with $0.1 \%$ solution of collagenase in PBS and incubated for $30 \mathrm{~min}$ at $37^{\circ} \mathrm{C}$. The obtained suspension was spun down and cultivated in Dulbecco's Modified Eagle's medium (DMEM) with 15\% fetal bovine serum (FBS, Gibco, Dublin, Ireland) $5 \mathrm{mM}$ HEPES, $2 \mathrm{mM}$ L-glutamine, and $20 \mathrm{ng} / \mathrm{ml}$ fibroblast growth factor (FGF, Biochrom, Cambridge, UK) in Petri dishes. After 2 passages HUVEC were seeded on plates covered with fibrin scaffolds or untreated plates (controls). Cells were cultivated during 6 passages. To confirm that we obtained endothelialderived cells we used flow-cytometry with specific labeled antibodies (Becton Dickinson, Franklin Lakes, USA): anti-CD34 APC, anti-CD90 FITC, anti-CD45 APC-Cy7, anti-CD105 PerCP-Cy 5.5, anti-CD73 PE, and anti-CD31 PE. Analysis was performed on the laser flow-cytometer BD FACSAria (Becton Dickinson) using the software FACSDiva 6.1.2. (Becton Dickinson) Immunophenotyping demonstrated that cells grown on all studied plates belonged to the HUVEC type having a phenotype CD31+CD105+CD73+CD90-CD34-CD45.

Mouse aortic endothelial cells (MAEC). MAEC (ThermoFisher Scientific, Waltham, USA) were grown on 96-well plates covered with fibrin scaffolds as described above, in Iscove's modified Dulbecco's medium (Sigma-Aldrich, St. Louis, USA) supplemented with $10 \%$ FBS and gentamicin $(50 \mu \mathrm{g} / \mathrm{ml})$. All cells were incubated at $37{ }^{\circ} \mathrm{C}$ in $5 \% \mathrm{CO}_{2}$.

Cancer cell culture. The lung cancer H1299 cell line was purchased from the American Type Culture Collection (ATCC, Manassas, VA, USA). H1299 cells were cultured in RPMI medium (Invitrogen Waltham, USA) supplemented with $10 \%$ FBS (Clontech, Kyoto, Japan) and $50 \mu \mathrm{g} / \mathrm{ml}$ gentamicin (Life Technologies Carlsbad, USA). Cells were incubated at $37{ }^{\circ} \mathrm{C}$ with $5 \% \mathrm{CO}_{2}$.

Chemicals and reagents. Adenosine diphosphate (ADP), dimethyl sulfoxide, MTT reagent, benzamidine, thrombin, and Superdex G-75 were purchased from Sigma-Aldrich. Collagen was purchased from RenaU (Kharkiv, Ukraine). Chromogenic substrate S2238 and C18 reversed phase HPLC columns were purchased from ThermoFisher Scientific. Anti-CD34 APC, anti-CD90 FITC, anti-CD45 APC-Cy7, anti-CD105 PerCP-Cy 5.5, anti-CD73 $\mathrm{PE}$, and anti-CD31 PE were purchased from Becton Dickinson. All other reagents were of chemical grade provided by local suppliers.

SDS-PAGE. The molecular weights and purity of proteins were determined by SDS-PAGE using $10 \%$ or $12 \%$ gels according to Laemmli [24]. Hydrolysis products of fibrinogen and fibrin by fibrinogenase were also analysed by SDS-PAGE under reducing conditions. 
FPLC chromatography. The mixture of fibrinogen $(15 \mathrm{mg} / \mathrm{ml})$ and protease $(0.01 \mathrm{mg} / \mathrm{ml})$ was incubated for $45 \mathrm{~min}$ in $0.05 \mathrm{M}$ Tris- $\mathrm{HCl}$ buffer of $\mathrm{pH} 7.4$ with $0.13 \mathrm{M} \mathrm{NaCl}$ (TBS) at room temperature. The reaction of hydrolysis was then stopped by addition of benzamidine at a final concentration $0.016 \mathrm{M}$. The mixture was gel-filtered through a Superdex G-75 column using the FPLC system ÄKTA (GE Healthcare, Pharmacia, Pittsburgh, USA). The column volume was $60 \mathrm{ml}$, with a flow rate of $2 \mathrm{ml} / \mathrm{min}$. Fractions that contained proteins or benzamidine were detected at $280 \mathrm{~nm}$ using the Spectrophotometer Optizen-POP (Optizen, Daejeon, Korea).

Proteinase activity detection. Activity of proteinase in the volume eluted from the Superdex G-75 column was detected using synthetic chromogenic substrate S2238 - H-D-Phe-Pip-Arg-pNA [25]. An aliquot of each fraction $(100 \mu \mathrm{l})$ was added to the well of a 96-well plate and mixed with $0.1 \mathrm{mM}$ of S2238 in $0.05 \mathrm{M}$ Tris- $\mathrm{HCl}$ buffer of $\mathrm{pH} 7.4$ containing $0.13 \mathrm{M} \mathrm{NaCl}$. Hydrolytic activity was continuously monitored at $405 \mathrm{~nm}$ [26].

HPLC chromatography. The chromatographic system Agilent 1100 (Agilent, Santa Clara, USA) was used for analysis of peptide fractions collected from the Superdex G-75 column with the C18 reversed phase HPLC column (ThermoFisher Scientific) at a pressure of 140 bar and flow rate of $1.5 \mathrm{ml}$ per min. During $80 \mathrm{~min}$, we used an increasing gradient of acetonitrile from 0 to $100 \%$ against buffered saline (0.15 M Tris $\mathrm{HCl}, \mathrm{pH} 6.5,0.13 \mathrm{M} \mathrm{NaCl})$.

MALDI-TOF. MALDI-TOF analysis of purified peptide derived from fibrinogen was performed using a Voyager-DE (Applied Biosystems, Waltham, USA). H+-matrix ionization of polypeptides with sinapine acid (Sigma-Aldrich) was used. Results were analyzed by Data Explorer 4.0.0.0 (Applied Biosystems) [27].

Aggregometry. Platelet aggregation measurements were based on changes in the turbidity of human platelet-rich plasma [28]. Studies were performed on the Aggregometer Solar AP2110 (SOLAR, Minsk, Belorussia) according to the recommendations of the manufacturer. Washed platelets $(200 \mu \mathrm{l})$ were added into the sample tube, mixed with $50 \mu$ lof fibrinogen $(9 \mathrm{mg} / \mathrm{ml})$ and activated by addition of $25 \mu \mathrm{CaCl}_{2}(0.025 \mathrm{M})$ and $25 \mu \mathrm{l}$ of platelet agonist ADP $(25 \mu \mathrm{M})$. Aggregation was registered for $5 \mathrm{~min}$ at $37^{\circ} \mathrm{C}$.

Calculation of generation time. For the characterization of culture growth we calculated the time of generation according to the formula: "Generation time" = "Time of culture growth"/"duplication of cells", where "duplication of cells" = $\ln$ ("number of collected cells"/“number of seeded cells")/ln2.

MTT test. Cell viability was measured by 3-(4, 5-diethylthiazoly-2-yl)-2,5-diphenyltetrazolium bromide (MTT) assay. Cells were plated in 96-well plates and were incubated with $100 \mu 1$ of complete medium containing $1 \mathrm{mg} / \mathrm{ml}$ MTT (3-(4,5-dimethylthiazol-2-yl)-2,5-diphenyltetrazolium bromide, Sigma-Aldrich) at $37^{\circ} \mathrm{C}$ for $4 \mathrm{~h}$ followed by solubilization with dimethyl sulfoxide (Sigma-Aldrich). The absorbance at $540 \mathrm{~nm}$ was measured with a microplate reader [29].

Scratch wound-healing test. The scratch wound-healing assay was applied as previously described [30 ]. It is a widely used approach for estimating cell migration, and is especially useful for the study of migration of cancer cells [31]. Briefly, $4 \times 10^{5}$ cells were seeded into 24 -well cell culture plates and allowed to grow to form a confluent monolayer $(24 \mathrm{~h})$. On the next day, the cells were serum-starved in RPMI medium containing $0.5 \%$ FBS for 24 prior to treatment. The monolayer was gently scratched with a sterile pipette tip to create a "scratch" $1 \mathrm{~cm}$ long. The wells were washed 2 times with $1 \mathrm{ml}$ of the growth medium to remove the debris and smooth the edge of the scratch. Lyophilized fibrinogen was reconstituted in $50 \mathrm{mM}$ Tris, $130 \mathrm{mM}$ $\mathrm{NaCl}, \mathrm{pH} 7.5$ prior to the treatment. Fresh medium containing $50 \mu \mathrm{g} / \mathrm{ml}$ of control or truncated fibrinogen was added to cells and cells were incubated in fibrinogen-containing media for $2 \mathrm{~h}$. After $2 \mathrm{~h}$, media was replaced with RPMI $+0.5 \%$ FBS and cells were incubated for up to $24 \mathrm{~h}$. The images of scratches were acquired at 0,12 and $24 \mathrm{~h}$ post treatment. The wound area was measured and the number of migrated cells were counted using ImageJ software (National Institutes of Health [NIH], Bethesda, MD, USA). The number of cells that migrated into a zone of scratching was normalized to the vehicle-treated wells (no fibrinogen).

Statistical analysis. Results are presented as means \pm standard deviation, calculated using Microsoft Excel (Microsoft Corp., Redmond, USA). Data were considered significant for $P<0.05$.

\section{Results}

Preparation of fibrinogen desB $\beta 1-42$. Proteolytic enzyme from the venom of Echis multisquamatis was previously described as the fibrinogenase 
targeted to N-terminal portions of B $\beta$-chains of human fibrinogen [32]. We incubated pure human fibrinogen $(15 \mathrm{mg} / \mathrm{ml})$ with protease $(0.01 \mathrm{mg} / \mathrm{ml})$ in TBS at room temperature and detected the compositions of polypeptide chains of fibrinogen using SDSPAGE. After 45 min $90 \%$ of B $\beta$-chains were cleaved and we detected the larger part of the remnant chain in the same zone as the $\gamma$-chain of fibrinogen (Fig. 1, A). This composition of mixture and time of incubation was selected for preparative hydrolysis. The reaction was terminated by the addition of $0.016 \mathrm{M}$ of benzamidine (an inhibitor of serine proteases) and inhibited the activity of the protease we used [33].

After incubation and addition of inhibitor, the mixture was fractionated using size-exclusion chromatography on a Superdex G-75 column. As shown in Fig. 1, B, we obtained a huge fraction of truncated fibrinogen (faction 5) and detected the elution of benzamidine by its absorbtion at $280 \mathrm{~nm}$ (fraction 6). We also used chromogenic substrate assay to detect the presence of proteinase in the fractions. The content of proteinase was too small for detection using optical density measurement but was enough for the detection of specific enzyme activity. Fractions from $60 \mathrm{ml}$ to $80 \mathrm{ml}$ of eluted volume contained different amounts of protease (fraction E). We collected whole eluted volume between fraction 5 and fraction 6 in an attempt to collect the fraction of peptides cleaved from fibrinogen by protease (fraction 7).

The collected fraction 7 was then further purified using HPLC-chromatography on a C-18 column. The major polypeptide peak was eluted by an increasing gradient of acetonitrile and collected for mass spectrometry (Fig. 2, A).

The performed MALDI-TOF analysis allowed us to detect the peak with the mass to charge ratio 4589 that corresponded to the polypeptide with molecular weight $4589 \mathrm{Da}$ (Fig. 2, B). According to the software program "Peptide Mass Calculator" (http:// www.peptidesynthetics.co.uk/tools/), the peptide with the molecular weight corresponded to the peptide "s qgvndneegffsarghrpldkkreeapslrpapppisgggyr", which was formed after cleavage of the peptide bond BRR42-A43. Thus, we confirmed that by using the limited proteolysis of fibrinogen by proteinase from the venom of Echis multisquamatis, we obtained the truncated form of fibrinogen - desB $\beta 1-42$ that was used in further studies.

Study of platelet aggregation. Platelet aggregation is strongly dependent on fibrinogen content and can be impossible without fibrinogen. To study the peculiarities of platelet aggregation in the presence of control fibrinogen or its truncated form desB $\beta 1-42$ we obtained the washed human platelets re-suspended in HEPES buffer. To control samples of platelet suspensions we added $1.5 \mathrm{mg} / \mathrm{ml}$ of control fibrinogen, to the studied samples an equal amount of fibrinogen desB $\beta 1-42$ was added. Platelet suspensions were incubated with fibrinogen in an aggregometer tube for $2 \mathrm{~min}$ and then platelets were activated by the addition of ADP or collagen as the most common agonists that act in a different manner. ADP is the agonist for $\mathrm{P} 2 \mathrm{Y} 1$ and $\mathrm{P} 2 \mathrm{Y} 12$ receptors that directly induce aggregation of platelets [34]. Collagen acts through the integrin receptor GPVI and induces platelet degranulation with following aggregation that occurs mainly under the granules constituent action [35].

We demonstrated that in both cases the initial rate of platelet aggregation did not differ (Fig. 3). ADP-stimulated aggregation was completely normal and achieved a maximal rate of $35 \%$ in the presence of native fibrinogen and in the presence of fibrinogen desBB1-42. However constant mixing of sample in the tube for aggregometry led to the dissociation of platelet aggregates and disaggregation of platelets in the sample with the truncated form of fibrinogen (Fig. 3, A).

We observed the same trace in the case of collagen-induced platelet aggregation (Fig. 3, $B)$. Here we observed not only disaggregation of platelets following maximal aggregation, but also a decreasing of the maximal aggregation rate on $10 \%$. Thus, we can conclude that the residue B $31-42$ of the fibrinogen molecule is not important for platelet aggregation but can increase the stiffness of the fibrinplatelet clot whether by forming additional points of contact between platelet receptors and fibrinogen or by stabilizing the structure of fibrinogen in the clot.

Study of proliferation of EC. Another important cellular component of the hemostasis involved in thrombus formation is EC. Fibrinogen is an important factor that mediates binding of other cells to EC, and also provides a scaffold for smooth muscle cells and EC during vessel tissue repair [36].

Here we studied two types of endothelial cells primary HUVEC culture and immortalized PAE cell culture. Both types of cell were grown on the scaffolds formed with monomeric fibrin derived from control or truncated fibrinogen. For this the surface of the culturea plate with a $35 \mathrm{~mm}$ diameter was covered by PBS. Then an equal volume of fibrino- 


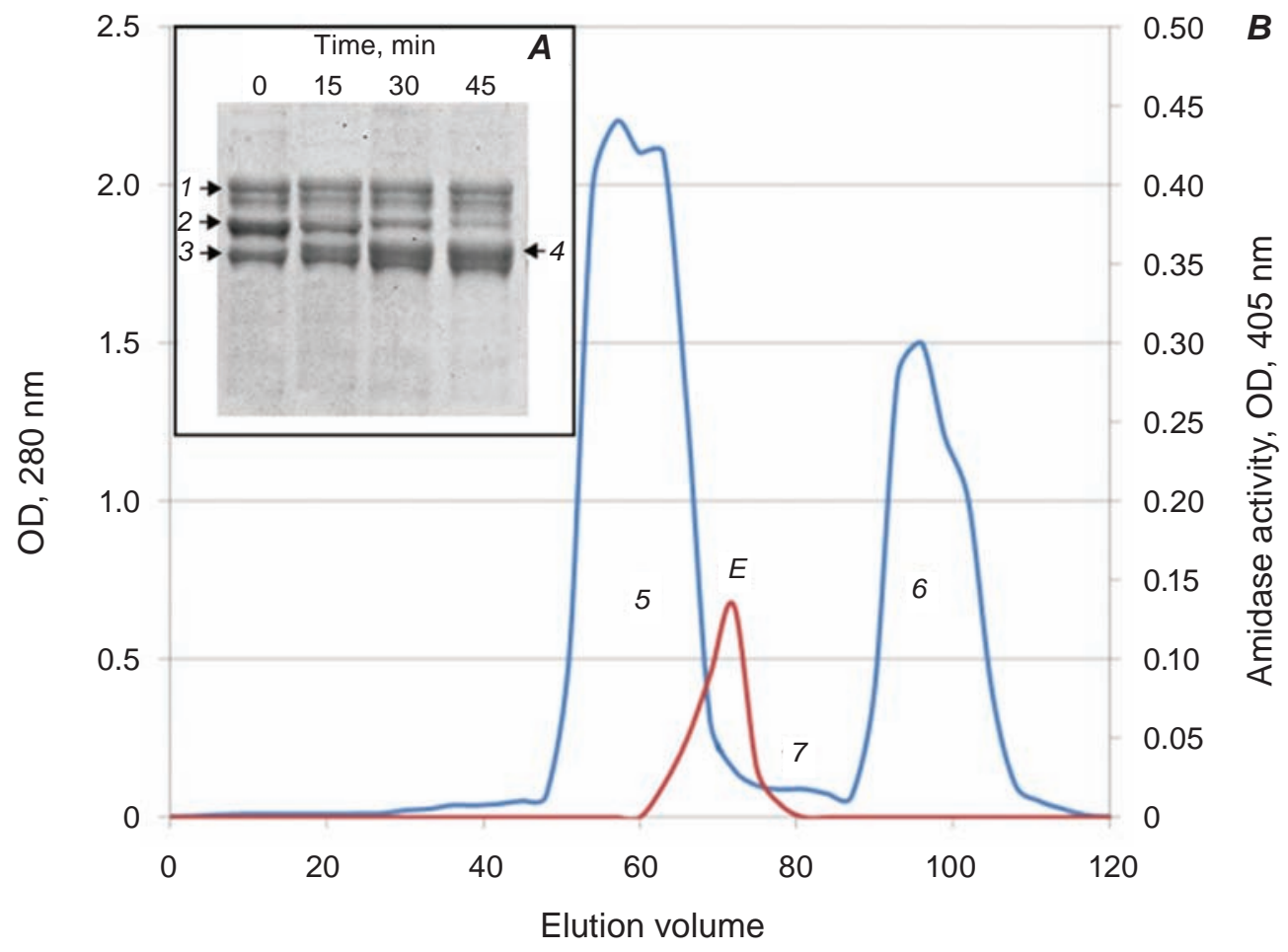

Fig. 1. Fibrinogen $(15 \mathrm{mg} / \mathrm{ml})$ digested by $0.010 \mathrm{mg} / \mathrm{ml}$ of fibrinogenase from the venom of Echis multisquamatis. A-SDS-PAGE of fibrinogen digested by fibrinogenase from the venom of Echis multisquamatis before and

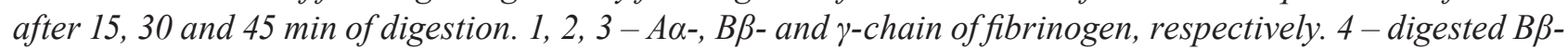
chain of fibrinogen. $\boldsymbol{B}$-Elution of fibrinogen from Superdex G-75 column after incubation with the enzyme. Fractions: 5 - truncated fibrinogen; 6 - benzamidine; 7 - peptide zone; $E$-enzyme; OD-optical density

gen solution in $0.125 \%$ acetic acid was added to the plate to reach a final concentration of $0.386 \mathrm{mg} / \mathrm{ml}$. Monomeric fibrin is insoluble at neutral $\mathrm{pH}$ so it was oligomerized and adhered to the surface of plate at the final concentration of $35 \mu \mathrm{g} / \mathrm{ml}$.

In our studies we compared the generation time of HUVEC calculated for the different passages on the scaffolds formed with fibrin desAB (peptide composition $\alpha 17-610$; B $\beta 15-461 ; \gamma 1-411$ ), fibrin desA $(\alpha 17-610 ; \mathrm{B} \beta 1-461 ; \gamma 1-411)$ and fibrin desAB $\beta 15-42$ ( $\alpha 17-610 ; B \beta 43-461 ; \gamma 1-411)$.

It was demonstrated that the generation time during the cultivation on fibrin desA and des $\mathrm{AB}$ was constant during the entire study. At the same time, cultivation on fibrin desAB $\beta 15-42$ led to the prolongation of generation time that indicated slower duplication of cells and less efficient growth of the culture of HUVEC (Fig. 4, A). These observations were obvious in the images obtained using inverted microscopy (Fig. 4, B).

Another model we used for studying the effect of the fibrinogen $\mathrm{B} \beta \mathrm{N}$-domain on $\mathrm{EC}$ growth was MAEC. Cells were cultivated in a 96-well plate, and the surface of the wells were modified with fibrin as described above. The vitality of MAEC was estimated using the MTT test. The substantial decrease of viability of MAEC grown on the scaffolds formed by fibrin desABß15-42 was observed (Fig. 5).

Thus, in two independent systems we demonstrated that the absence of the $\mathrm{B} \beta \mathrm{N}$-domain prominently affected the ability of fibrin to support EC proliferation. The increasing of the observed effect from passage to passage in the case of HUVEC can indicate some regulatory role of the interaction of the B $315-42$ fragment with EC, possibly occurring through recently described interactions with VLDLR. Both HUVEC and MAEC cell lines confirmed the exceptional role of the $\mathrm{B} \beta 15-42$ fragment in fibrin(ogen) binding to EC.

Study of motility of cancer cells. Having sites of interactions with cancer cells on its surface, fibrinogen can stimulate cancerogenesis, as well as promote tumor growth and invasion [37]. Using our model, we estimated the role of the B $\beta 1-42$ fragment of fibrinogen in the motility of the lung cancer cell line H1299. 


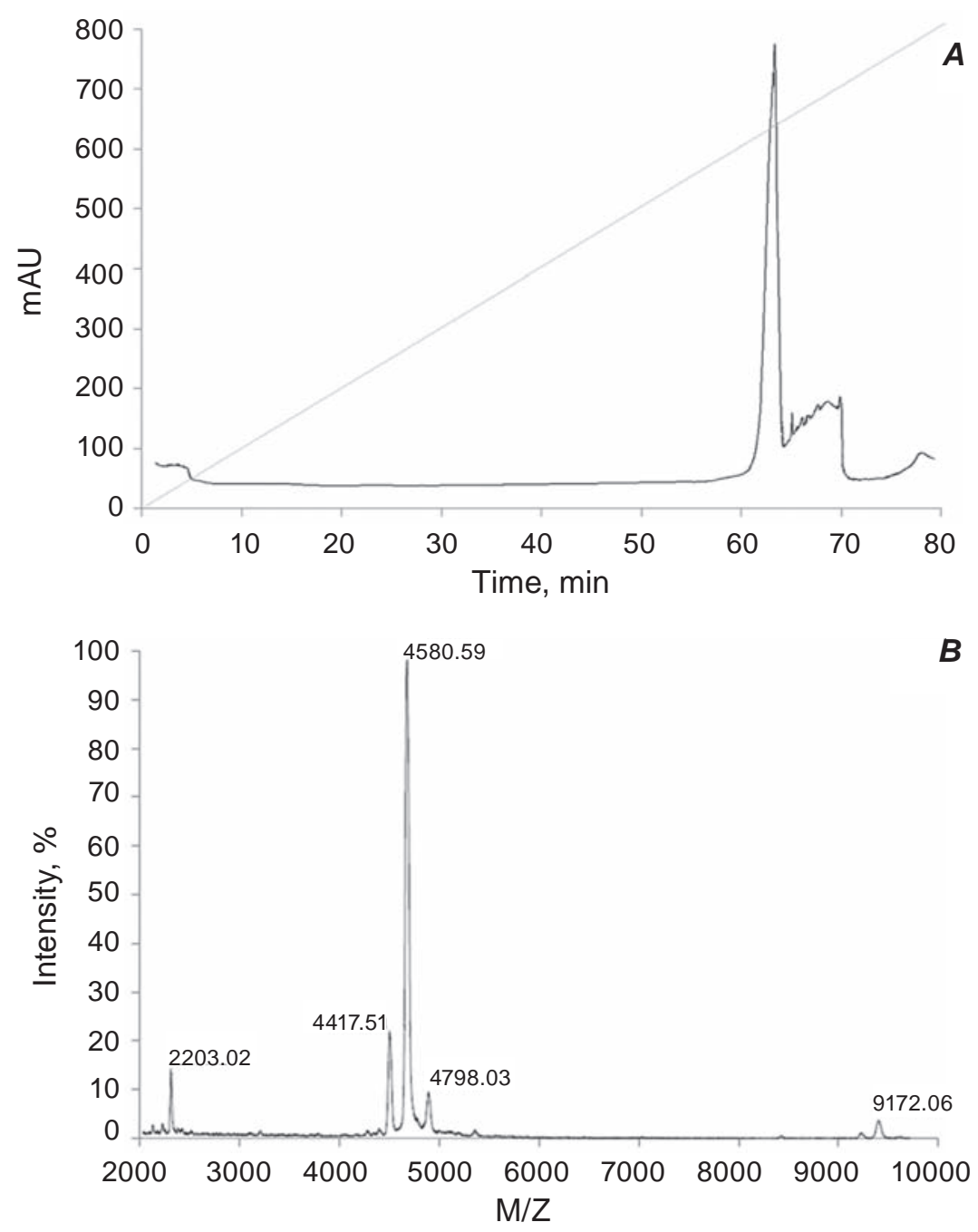

Fig. 2. Protease-digested peptide. A - Purification of protease-digested peptide using HPLC-chromatography on a C-18 column. The elution was performed using a linear gradient of acetonitrile from 0 to $100 \%$ against buffered saline. $\boldsymbol{B}-$ MALDI-TOF spectra of peptide digested from fibrinogen by protease and purified using size-exclusion chromatography on a Superdex G-75 column followed by HPLC on phenyl-sepharose. M/Zmass to charge ratio

For these experiments we prepared monolayers of H1299 cells, generated scratches and observed cell migration over time in the presence of control or truncated fibrinogen $(0.05 \mathrm{mg} / \mathrm{ml})$. As shown in Fig. 9, desB $\beta 1-42$ fibrinogen modulates the motility of H1299 cells in vitro. This effect can also be observed in Fig. 6.

By this preliminary experiment we demonstrated fibrinogen lacking the B $\beta 1-42$ region was a less effective scaffold for cancer cell proliferation. Thus, this fragment is possibly important for fibrinogen binding to cancer cell receptors. It is still unclear whether it can interact with CAM-receptors as the $\gamma 117-133$ residue of fibrinogen. It would also be important to study the direct effect of the B $\beta 1-42$ fragment on the proliferation of cancer cells. Using the limited proteolysis technique we obtained a very useful model for testing on additional cancer cell lines. On the other hand, other receptors that can bind fibrinogen must be looked for more precisely on the surface of cancer cells, as interactions of fibrinogen with cancer cells could be a target for anticancer therapy.

\section{Discussion}

Using protease from Echis multisquamatis venom we obtained fibrinogen lacking the B $\beta 1-42$ fragment and compared it to the native uncleaved 

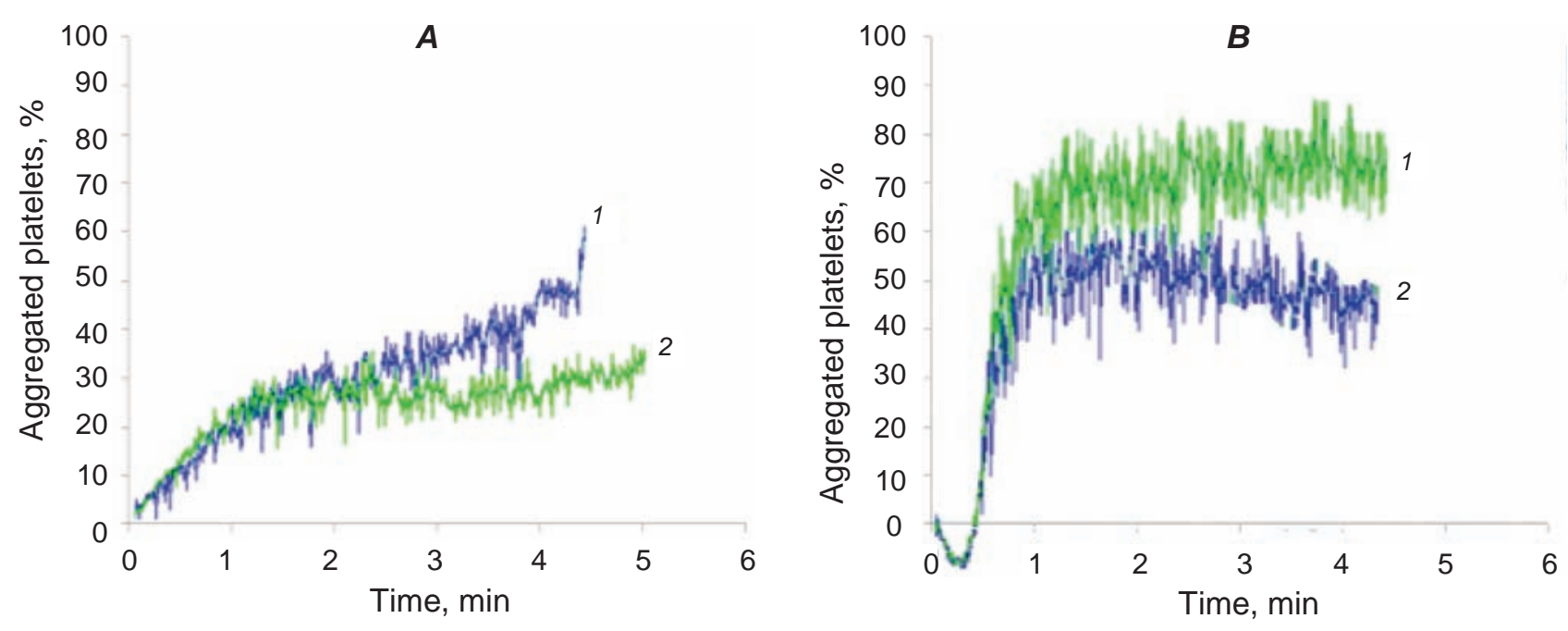

Fig. 3. Aggregation of washed platelets activated by (A) $2 \mu M$ of ADP or (B) $2.5 \mathrm{mg} / \mathrm{ml}$ of collagen in the presence of (1) native fibrinogen or (2) fibrinogen desB $\beta 1-42$. Curves of typical experiments, $n=5$

$\boldsymbol{A}$

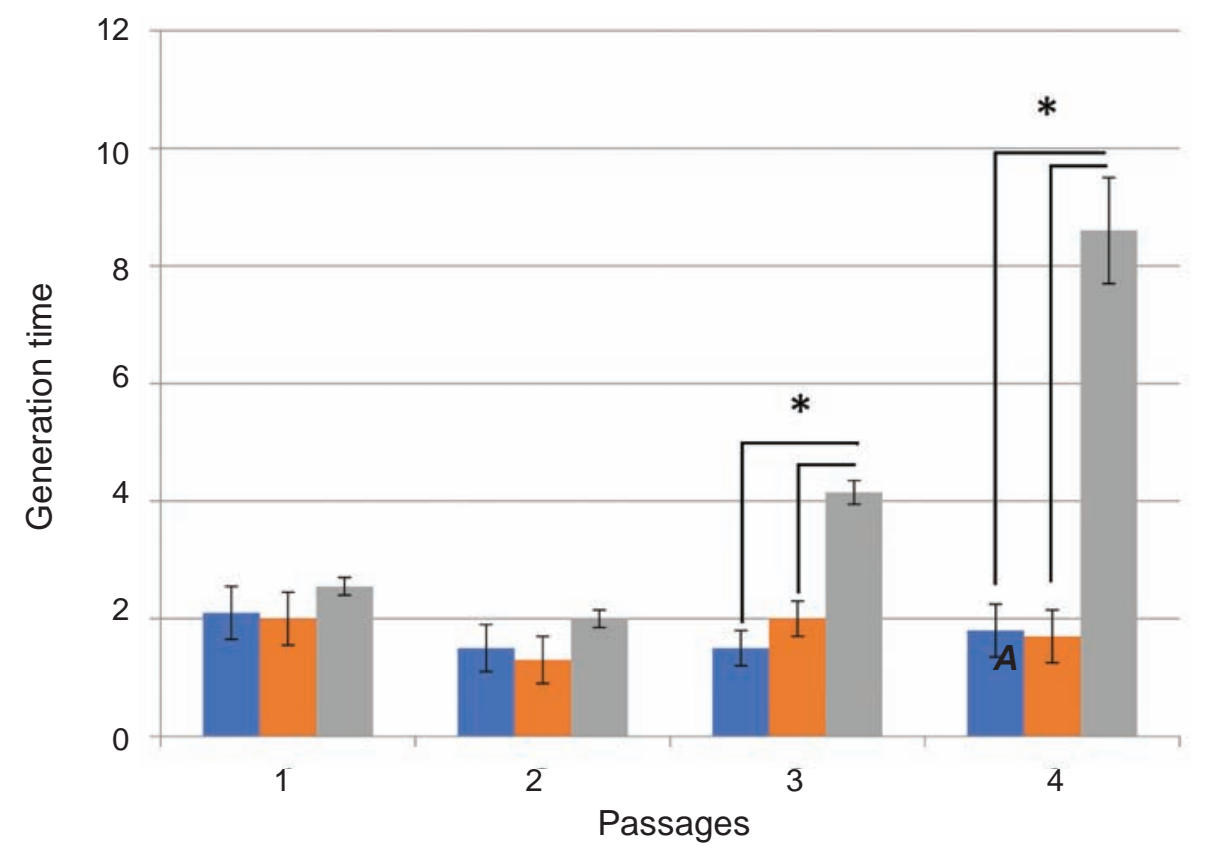

$B$
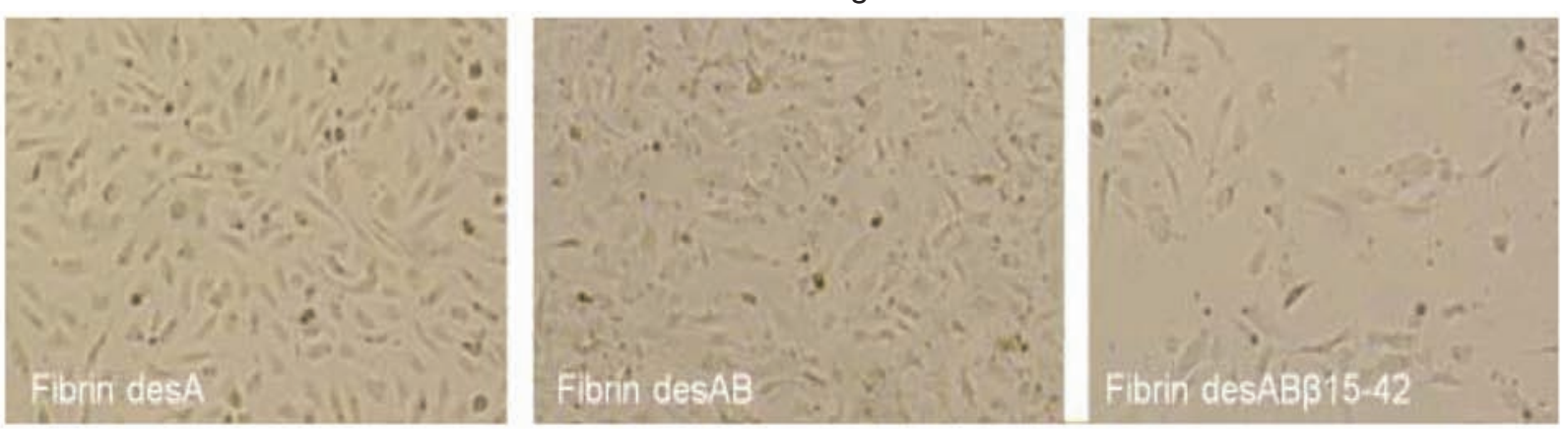

Fig. 4. A - Generation time of endothelial cells cultivated on the scaffolds formed by fibrin desA (blue bars), desAB (orange bars) and desAB B15-42 (grey bars). 1-4 - number of the cell passages. Result is significant for $P<0.05$. B - Typical view of endothelial cells cultivated on the scaffolds formed by fibrin desA, desAB and desABB15-42 (7 $7^{\text {th }}$ passage) 


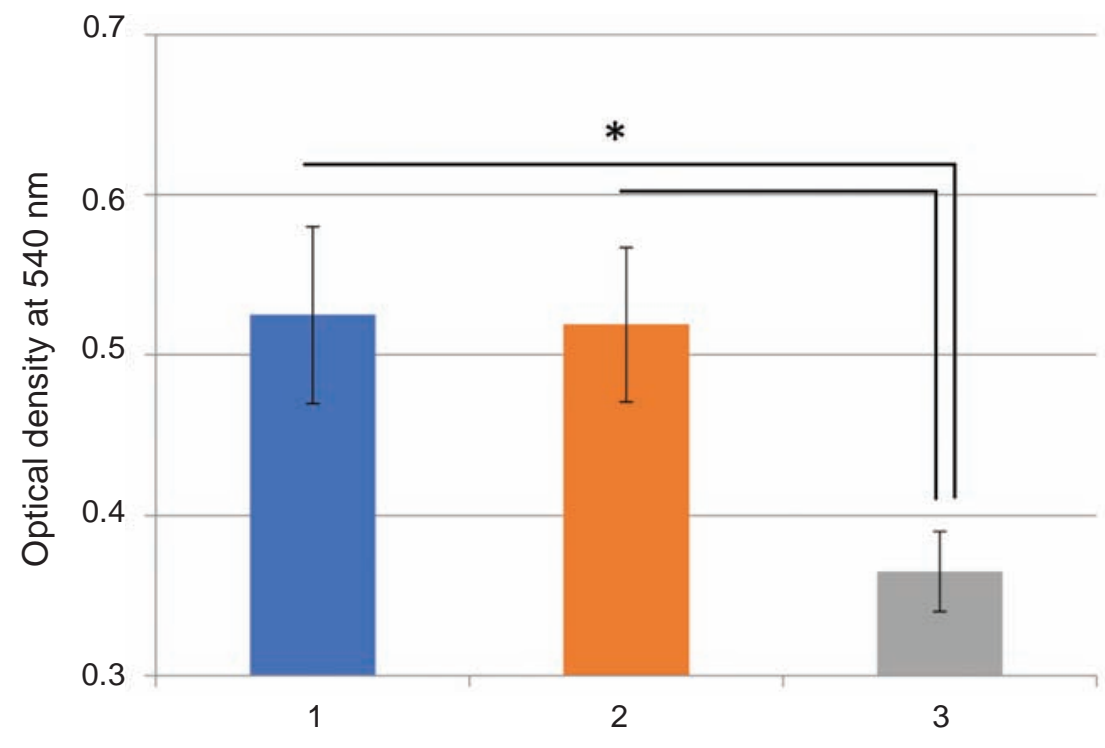

Fig. 5. Vitality of mouse aorta endothelial cells (MAEC) on the scaffolds formed by (1) fibrin desA, (2) desAB, and (3) desABß15-42. Result is significant for $\mathrm{P}<0.05$

$A$

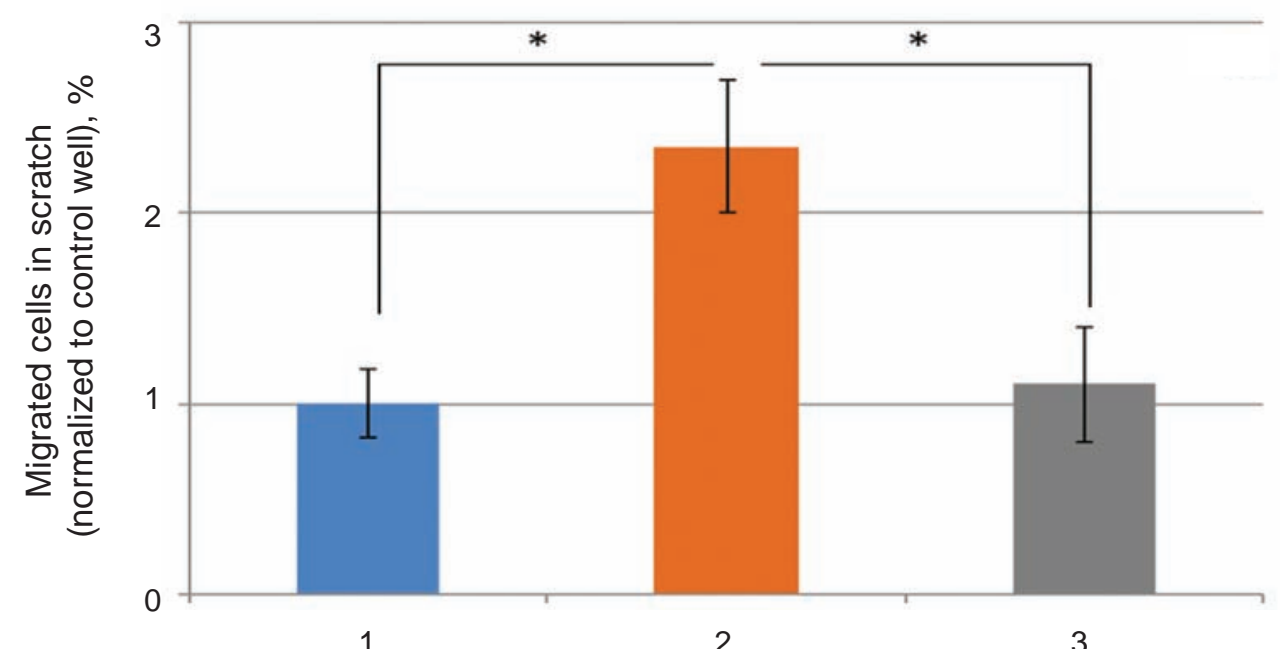

1

2

3

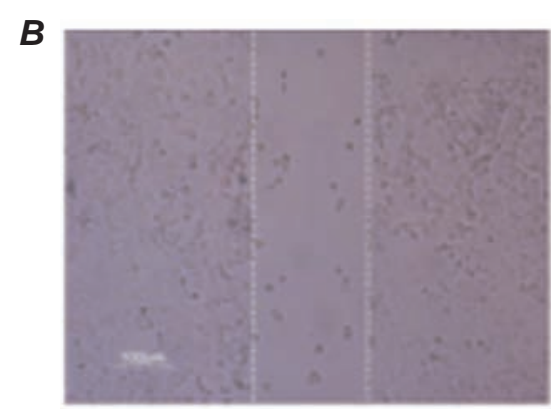

1

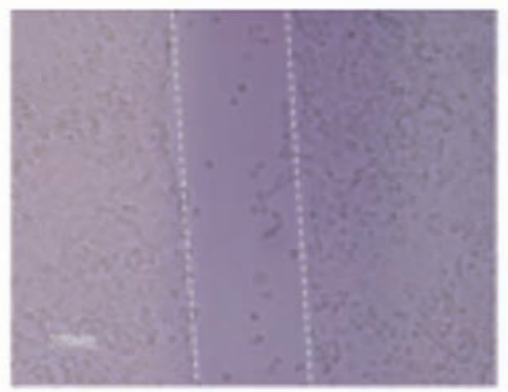

2

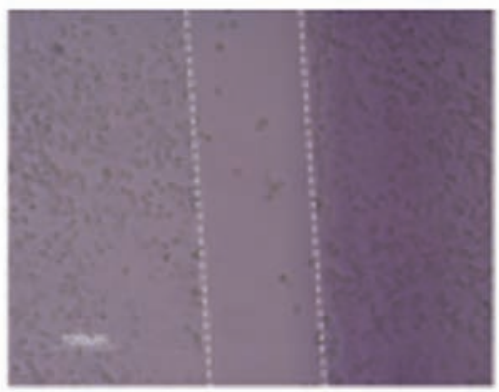

3

Fig. 6. H1299 cells in vitro in the presence of (2) native and (3) desBB1-42 fibrinogen 1 - control sample without addition of fibrinogen. A - Motility of H1299 cells. Result is significant for $P<0.05$. B - Typical experiment in scratch wound-healing test: migration of H1299 cells into the scratched zone in the presence of native or desBß1-42 fibrinogen. Zones of the original scratch are marked by white lines 
molecule in studies of aggregation of platelets, proliferation of EC and migration of cancer cells. The efficacy of all these processes were decreased in the presence of desB $\beta 1-42$ fibrinogen in comparison to the native one. The findings allowed us to conclude that the $\mathrm{B} \beta 1(15)-42$ fragment of fibrin(ogen) contributed to the efficient interaction with platelets, EC and cancer cells.

However, these observations were rather indirect. We studied the processes in the presence of fibrinogen without the B $\beta 1-42$ fragment, observing the effects of cell interactions with the rest of the molecule. These results must be assessed in combination with the results that were obtained using more direct methods. To probe the role of distinct parts of the residue $\mathrm{B} \beta 1-42$ in physiological processes one may use recombinant technology to obtain fibrinogen with amino-acid substitutions [38, 39], and monoclonal antibodies $[40,41]$ or peptides $[42,43]$ to block some part of the residues.

Our approach based on limited proteolysis has some advantages. In particular we are working with the delicately cropped native fibrinogen molecule that has its structure, glycosylation and conformation preserved; this is impossible when using recombinant analogues. Also, monoclonal antibodies or their Fab-fragments, even polypeptides, can cause non-specific spatial obstacles for intramolecular interactions. Using truncated forms of fibrinogen allowed us to avoid these limitations.

Taken together, from our data and the data obtained by other approaches we can assume the $\mathrm{B} \beta \mathrm{N}$-domain of fibrinogen is an important center of fibrin(ogen) interactions with cellular receptors that can act by stabilizing the structure of the molecule (as in the case of platelet aggregation) as well as interacting directly with cellular receptors (as in the case of EC). Being also obligatory for fibrin polymerization, the $\mathrm{B} \beta \mathrm{N}$-domain can be a target of therapeutics that would decrease not only thrombus formation, but also decrease fibrin(ogen) adhesion to endothelium or prevent metastasis of cancer cells.

Conflict of interest. Authors have completed the Unified Conflicts of Interest form at http://ukrbiochemjournal.org/wp-content/uploads/2018/12/ coi_disclosure.pdf and declare no conflict of interest.

Acknowledgement. We thank for Cedars-Sinai Medical Center's International Research and Innovation in Medicine Program, the Association for Re- gional Cooperation in the Fields of Health, Science and Technology (RECOOP HST Association) for their support of our organization as a participating Cedars-Sinai Medical Center - RECOOP Research Centers (CRRC).

\section{АГРЕГАЦІЯ ТРОМБОЦИТІВ, ПРОЛІФЕРАЦІЯ ЕНДОТЕЛІОЦИТІВ І МІГРАЦІЯ РАКОВИХ КЛІТИН ОПОСЕРЕДКОВАНІ Вß1(15)-42 ФРАГМЕНТОМ ФІБРИНОГЕНУ}

\author{
Є. М. Стогнійі, М. В. Рижикова ${ }^{1}$, \\ А. В. Ребрієв ${ }^{1}$ М. Д. Кучма ${ }^{2}$, Р. Ю. Марунич ${ }^{1}$, \\ В. О. Чернишенко ${ }^{1 凶}$ В. А. Шаблій ${ }^{2}$, \\ Н. М. Липова ${ }^{3}$ О. Ю. Сломінський \\ Л. В. Гарманчук ${ }^{4}$ Т. М. Платонова ${ }^{1}$, \\ С. В. Комісаренко ${ }^{1}$ \\ ${ }^{1}$ Інститут біохімії ім. О.В. Палладіна \\ НАН України, Київ, Україна; \\ ${ }^{2}$ Інститут клітинної терапії, Київ, Україна; \\ зУніверситет Луїсвілла, США; \\ ${ }^{4}$ ННЦ "Інститут біології та медицини", \\ Київський національний університет \\ імені Тараса Шевченка, Україна; \\ 凶e-mail: bio.cherv@gmail.com
}

Молекула фібриногену містить численні ділянки зв'язування для різних типів клітинних рецепторів і виконує роль сполучної ланки між системою зсідання крові та клітинною адгезією. У цій статті описано отримання форми фібриногену, позбавлену фрагменту В $\beta 1$ 42 за допомогою спрямованого протеолізу, для вивчення ролі цієї послідовності у адгезивних властивостях тромбоцитів, ендотеліоцитів і ракових клітин. Фібриноген та фібрин, позбавлені В $\beta 1-42$ та В $\beta 15-42$ фрагментів відповідно (des $\beta 1$ 42 фібриноген i desAB $\beta 15-42$ фібрин), отримано за допомогою протеїнази з отрути Echis multisquamatis. Відщеплений фрагмент отримували за допомогою HPLC та ідентифікували 3 використанням MALDI-TOF. ADP- i колаген-індуковану агрегацію тромбоцитів за пристуності фібриногену desB $\beta 1-42$ вивчали за допомогою агрегометра. Проліферацію клітин аорти миші (MAEC) і клітин пуповинної вени людини (HUVEC) вивчали 3 використанням фібрину desAB $\beta 15-42$ як матриці. Виживаність клітин МАЕС оцінювали з використанням МТТтесту. Для оцінки проліферативної активності HUVEC розраховували час подвоєння. 
Міграцію клітин раку легенів Н1299 вивчали за допомогою in vitro тесту подряпини. Пряме порівняння поведінки клітин за присутності нативної та частково гідролізованої форм показало порушення процесів клітинної адгезії за пристуності фібриногену desB $\beta 1-42$ та фібрину desBß15-42. Ступінь агрегації тромбоцитів незначно знижувався за присутності фібриногену $\operatorname{desB} \beta 1-42$, однак було виявлено дезагрегацію тромбоцитів на рівні 15-20\%. Ми також виявили значне зниження інтенсивності поділу клітин HUVEC та інгібування виживаності клітин лінії MAEC вирощених на матриці 3 desAB $\beta 15-42$ фібрину. Крім того, фібриноген $\operatorname{des} B \beta 1-42$ модулював рухливість клітин лінії Н1299 in vitro i знижував інтенсивність “заростання подряпини” до 20\% порівняно 3 повнорозмірним фібриногеном. Показано, що фрагмент 1-42 $\mathrm{B} \beta \mathrm{N}$-домену молекули фібриногену не $\epsilon$ необхідним для агрегації тромбоцитів, однак вносить вклад у формування фібриновотромбоцитарного тромбу на пізніших стадіях. У той же час, цей фрагмент може бути важливим для забезпечення міцних міжклітинних контактів та виживаності ендотеліоцитів. Також амінокислотна послідовність 1-42 BßNдомену підтримує міграцію ракових клітин, що дозволяє розглядати взаємодії з фібриногеном як потенційну мішень протиракової терапії. Фрагмент В $\beta 1-42$ молекули фібриногену вносить вклад у ефективність міжклітинних взаємодій різних типів клітин, включаючи тромбоцити, ендотеліоцити і ракові клітини.

К л ю ч о в і с лов в: фібриноген, адгезія, міграція клітин, ендотелій, проліферція клітин, тромбоцити.

\section{References}

1. Medved L, Weisel JW. Recommendations for nomenclature on fibrinogen and fibrin. $J$ Thromb Haemost. 2009; 7(2): 355-359.

2. Fuss C, Palmaz JC, Sprague EA. Fibrinogen: structure, function, and surface interactions. $J$ Vasc Interv Radiol. 2001; 12(6): 677-682.

3. Weisel JW, Litvinov RI. Fibrin formation, structure and properties. Subcell Biochem. 2017; 82: 405-456.

4. Remjin JA, Ijsseldijk MJV, De Groot PG. Role of the fibrinogen $\gamma$-chain sequence $\gamma 316-322$ in platelet-mediated clot retraction. $J$ Thromb Haemost. 2003; 1(10): 2245-2246.
5. Hantgan RR, Stahle MC, Lord ST. Dynamic regulation of fibrinogen: integrin $\alpha \mathrm{IIb} \beta 3$ binding. Biochemistry. 2010; 49(43): 9217-9225.

6. Chen CS, Chou S-H, Thiagarajan P. Fibrin(ogen) peptide $\mathrm{B} \beta$ 15-42 inhibits platelet aggregation and fibrinogen binding to activated platelets. Biochemistry. 1988; 27(16): 6121-6126.

7. Adelman B, Gennings C, Strony J, Hanners E. Synergistic inhibition of platelet aggregation by fibrinogen-related peptides. Circ Res. 1990; 67(4): 941-947.

8. Hamaguchi M, Bunce LA, Sporn LA, Francis CW. Spreading of platelets on fibrin mediated by the amino terminus of the $\beta$ chain including peptide $\beta$ 15-42. Blood. 1993; 81(9): 2348-2356.

9. Bach TL, Barsigian C, Yaen CH, Martinez J. Endothelial cell VE-cadherin functions as a receptor for the beta15-42 sequence of fibrin. $J$ Biol Chem. 1998; 273(46): 30719-30728.

10. Martinez J, Ferber A, Bach TL, Yaen CH. Interaction of fibrin with VE-cadherin. Ann NY Acad Sci. 2001; 936: 386-405.

11. Yakovlev S, Medved L. Interaction of fibrin(ogen) with endothelial cell receptor VE-Cadherin: localization of the fibrin-binding site within the third extracellular VE-cadherin domain. Biochemistry. 2009; 48(23): 5171-5179.

12. Yakovlev S, Gao Y, Cao C, Chen L, Strickland DK, Zhang L, Medved L. Interaction of fibrin with VE-cadherin and anti-inflammatory effect of fibrin-derived fragments. J Thromb Haemost. 2011; 9(9): 1847-1855.

13. Yakovlev S, Mikhailenko I, Cao C, Zhang L, Strickland DK, Medved L. Identification of VLDLR as a Novel Endothelial Cell Receptor for Fibrin That Modulates Fibrin-Dependent Transendothelial Migration of Leukocytes. Blood. 2012; 119(2): 637-644.

14. Yakovlev S, Medved L. Interaction of fibrin with the very low density lipoprotein receptor: further characterization and localization of the fibrin-binding site. Biochemistry. 2015; 54(30): 4751-4761.

15. Garnacho C, Serrano D, Muro S. A fibrinogenderived peptide provides intercellular adhesion molecule-1-specific targeting and intraendothelial transport of polymer nanocarriers in human cell cultures and mice. $J$ Pharmacol Exp Ther. 2012; 340(3): 638-647.

16. Duperray A, Languino LR, Plescia J, McDowall A, Hogg N, Craig AG, Berendt AR, 
Altieri DC. Molecular identification of a novel fibrinogen binding site on the first domain of ICAM-1 regulating leukocyte-endothelium bridging. J Biol Chem. 1997; 272(1): 435-441.

17. Simpson-Haidaris PJ, Rybarczyk B. Tumors and fibrinogen. The role of fibrinogen as an extracellular matrix protein. Ann N Y Acad Sci. 2001; 936: 406-425.

18. Roche Y, Pasquier D, Rambeaud JJ, Seigneurin D, Duperray A. Fibrinogen mediates bladder cancer cell migration in an ICAM-1-dependent pathway. Thromb Haemost. 2003; 89(6): 10891097.

19. Lin Y-C, Shun C-T, Wu M-S, Chen C-C. A novel anticancer effect of thalidomide: Inhibition of intercellular adhesion molecule-1 mediated cell invasion and metastasis through suppression of nuclear factor-KB. Clin Cancer Res. 2006; 12(23): 7165-7173.

20. Bonan S, Albrengues J, Grasset E, Kuzet SE, Nottet N, Bourget I, Bertero T, Mari B, Meneguzzi G, Gaggioli C. Membrane-bound ICAM-1 contributes to the onset of proinvasive tumor stroma by controlling acto-myosin contractility in carcinoma-associated fibroblasts. Oncotarget. 2017; 8(1): 1304-1320.

21. Belitser VA, Varetska TV, Manjakov VPh. On the model for the fibrinogen molecule. Consecutive stages of fibrin polymerization. Thromb Res. 1973; 2(6): 567-577.

22. Solov'ev DA, Ugarova TP. Isolation and Characteristics of Alpha-Specific ThrombinLike Enzymes From Venoms of the Common Pit Viper (Agkistrodon Halys Halys) and the Eastern Pit Viper (The Central Asian Subspecies Agkistrodon Halys Blomhoffii). Biokhimiia. 1993; 58(8): 1221-1233. (In Russian).

23. Chernyshenko V, Shteinberg K, Lugovska N, Ryzhykova M, Platonova T, Korolova D, Lugovskoy E. Preparation of highly-concentrated autologous platelet-rich plasma for biomedical use. Ukr Biochem J. 2019; 91(2): 19-27.

24. Laemmli UK. Cleavage of structural proteins during the assembly of the Head of bacteriophage T4. Nature. 1970; 227(5259): 680-685.

25. Chernyshenko VO. Limited proteolysis of fibrinogen by fibrinogenase from Echis multisquamatis venom. Protein J. 2015; 34(2): 103-104.

26. Gershkovich AA, Kibirev VK. Chromogenic and fluorogenic peptide substrates of proteolytic enzymes. Bioorg Khim. 1988; 14(11): 1461-1488. (In Russian).

27. Chapman JR, Ed., Mass Spectrometry of Proteins and Peptides. Humana Press. Totowa, New Jersey. 2000, 538 p.

28. Cattaneo M, Cerletti C, Harrison P, Hayward CP, Kenny D, Nugent D, Nurden P, Rao AK, Schmaier AH, Watson SP, Lussana F, Pugliano MT, Michelson AD. Recommendations for the standardization of light transmission aggregometry: A consensus of the working party from the Platelet Physiology Subcommittee of SSC/ISTH. J Thromb Haemost. 2013; 11(6): 1183-1189.

29. Gao W, Chen SR, Wu MY, Gao K, Li YL, Wang HY, Li CY, Li H. Methylprednisolone exerts neuroprotective effects by regulating autophagy and apoptosis. Neural Regen Res. 2016; 11(5): 823-828.

30. Liang C, Park A, Guan J. In vitro scratch assay: a convenient and inexpensive method for analysis of cell migration in vitro. Nat Protoc. 2007; 2(2): 329-333.

31. Mouritzen VM, Jenssen H. Optimized scratch assay for in vitro testing of cell migration with an automated optical camera. J Vis Exp. 2018;(138): e57691.

32. Chernyshenko V, Platonova T, Makogonenko Y, Rebriev A, Mikhalovska L, Chernyshenko T, Komisarenko S. Fibrin(ogen)olytic and platelet modulating activity of a novel protease from the Echis multisquamatis snake venom. Biochimie. 2014; 105: 76-83.

33. Chernyshenko VO, Myasnikova MP, Platonova TM, Lougovskoi EV, Makogonenko EM. Purification and biochemical characterisation of fibrinogenase from Echis multisquamatis venom. Biotechnology. 2010; 3(1): 27-34. (In Ukranian).

34. Zhou L, Schmaier AH. Platelet aggregation testing in platelet-rich plasma description of procedures with the aim to develop standards in the field. Am J Clin Pathol. 2005; 123(2): 172183.

35. Bryckaert M, Rosa J-P, Denis CV, Lenting PJ. Of von Willebrand factor and platelets. Cell Mol Life Sci. 2015; 72(2): 307-326.

36. Brown AC, BarkerTH. Fibrin-based biomaterials: Modulation of macroscopic properties through rational design at the molecular level. Acta Biomater. 2014; 10(4): 1502-1514. 
37. Kwaan HC, Lindholm PF. Fibrin and fibrinolysis in cancer. Semin Thromb Hemost. 2019; 45(4): 413-422.

38. Moen JL, Gorkun OV, Weisel JW, Lord ST. Recombinant BbetaArg14His fibrinogen implies participation of N-terminus of Bbeta chain in desAA fibrin polymerisation. Blood. 2003. 102(7): 2466-2471.

39. Soya K, Terasawa F, Okumura N. Fibrinopeptide A release is necessary for effective B:b interactions in polymerisation of variant fibrinogens with impaired A:a interactions. Thromb Haemost. 2013; 109(2): 221-228.

40. Lugovskoi EV, Makogonenko EM, Chudnovets VS, Derzskaya SG, Gogolinsikaja GK, Kolesnikova IN, Bukhanevich AM, Komisarenko SV. The study of fibrin polymerisation with monoclonal antibodies. Biomed Sci. 1991; 2: 249-296.

41. Morris TA, Marsh JJ, Fagnani R, Hagan M, Moser KM. Degree of polymer organization decreases the binding of a monoclonal antibody raised against the beta-chain amino terminus of fibrin. Thromb Haemost. 1997; 77(4): 704-709.

42. Lugovskoy EV, Gritsenko PG, Kapustianenko LG, Kolesnikova IN, Chernishov VI, Komisarenko SV. Functional role of B $\beta$-chain $\mathrm{N}$-terminal fragment in the fibrin polymerization process. FEBS J. 2007; 274(17): 4540-4549.

43. Doolittle RF, Pandi L. Probing the beta-chain hole of fibrinogen with synthetic peptides that differ at their amino termini. Biochemistry. 2007; 46(35): 10033-10038. 